Vol. XXV, No. 6. JUNE, $1922 . \quad$ No. 292.

ABSTRACTS FROM THE ORIGINAL PAPERS.

\title{
ON THE PREPARATION OF HELIOTROPINE FROM ISOSAFROL BY OZONE.
}

By Shōichirō Nagai, Kōgakushi.

[Received March 15, 1922.]

The author observed, in his previous studies (The Fournal of Chemical Industry, Tokyo, Japan, I920, 23, 56 \& 151 ; 1922, 25, 52) on the preparation of heliotropine, that the yield of heliotropine at the oxidation of isosafrol by potassium bichromate or permanganate could hardly be higher than $40-50 \%$, owing to the polymerisation of isosafrol to a resinous substance and to the excessive oxidation of heliotropine (piperonal) to piperonylic acid. The oxidation method by ozone is one of the most preferable processes to avoid these sub-reactions and obtain a better result.

The ozonized air was obtained by an ozone-generator or ozonizer with Io Berthelot-Siemens ozone tubes (C. Harries, Ann., 343, 341; 374, 310) and its ozone content was about $2.0-3.5 \%$. By using this ozonized air, the ozonization of isosafrol, the decomposition of isosafrol-ozonide and the preparation of heliotropine were studied as follows.

(I) The Ozonization of Isosafrol. Isosafrol was ozonized in the solution of perfectly dried solvent, e. g., carbon tetrachloride, tetrachloroethane, chloroform, glacial acetic acid, toluene or xylene. $10 \mathrm{grs}$. of isosafrol was dissolved in 10-15 times of the solvent, the ozonized air was passed in at the room temperature, and then the ozonization occurred very easily.

(2) The Separation of Isosafrol-ozonide. The ozonide solution above obtained was coloured slightly yellowish brown. The solvent was separated by 
the careful distillation in vacuo. The ozonide was also separated from the solvent by adding 2-3 times of petroleum ether (its boiling point being nearly equal to that of the solvent used). The separated ozonide was deep reddish brown, viscous oily substance, and had a characteristic odour. But it decomposed itself spontancously even at the room temperature, and its decomposition products were acetaldehyde, heliotropine, piperonylic acid and a dark brown resinous substance.

(3) The Continuous Ozonization. When the solvent was first mixed with 2-3 times of petroleum ether as above described and then used as the ozonizing solvent, the isosafrol-ozonide deposited to the bottom as it was produced. To the waste mixed solution, isosafrol was again added and could be ozonized equally well. Therefore, the continuous ozonization was performed by using the mixed solvent above described, adding isosafrol continuously and separating the ozonide thus depositing to the bottom.

(4) The Decomposition of Isosafrol-ozonide. Many methods of decomposition of the isosafrol-ozonide were studied as follows :

(a) The ozonide of isosafrol decom! osed itself very easily, as above described.

(b) The ozonide in the solvent was decomposed by warming it at about $40-50^{\circ} \mathrm{C}$.

(c) The ozonide solution was also decomposed by stirring it with water at the room temperature or about at $40-50^{\circ} \mathrm{C}$.

But by these decomposition methods, many resinous substances and overoxidized piperonylic acid were produced, and the yield of heliotropine was reduced very much. From the decomposition formulae of ozonide to two aldehydic compounds (C. Harries, Untersuchungen über das Ozon und seine Einwirkungen auf organischen Verbindungen, 1903-1916), it is clear that one atom of oxygen is to be set free which must be rejected by some reducing agent.

(d) The ozonide in glacial acetic acid solution was decomposed and reduced simultaneously by adding water and zinc powder, the reducing agent being the hydrogen generated by the action of acetic acid on zinc powder.

(e) The reduction was done by blowing hydrogen gas into the ozonide solution, the decomposition of ozonide being performed at the same time 
by water or warming as above described.

By these combinations of decomposition of ozonide and reduction of free oxygen, the by-products were reduced and better yield of heliotropine was obtained.

(f) The ozonide solution was stirred with excess of saturated solution of sodium bisulphite $(35-36 \%)$ and the total contents solidified to a white mass. By this process, three reactions-(I) the decomposition of ozonide by water of the sodium bisulphite solution, (2) the reduction of the free oxygen by the sodium bisulphite, and (3) the separation of thus produced heliotropine as a crystalline addition product with the remaining sodium bisulphite-occurred simultaneously and a very good result was obtained. By combining this decomposition method with the continuous ozonization above described, the.author obtained the yield of about $85 \%$, which was never obtained heretofore.

The comparative results of these ozonization, separation and decomposition of ozonide and reduction of oxygen are tabulated as follows:

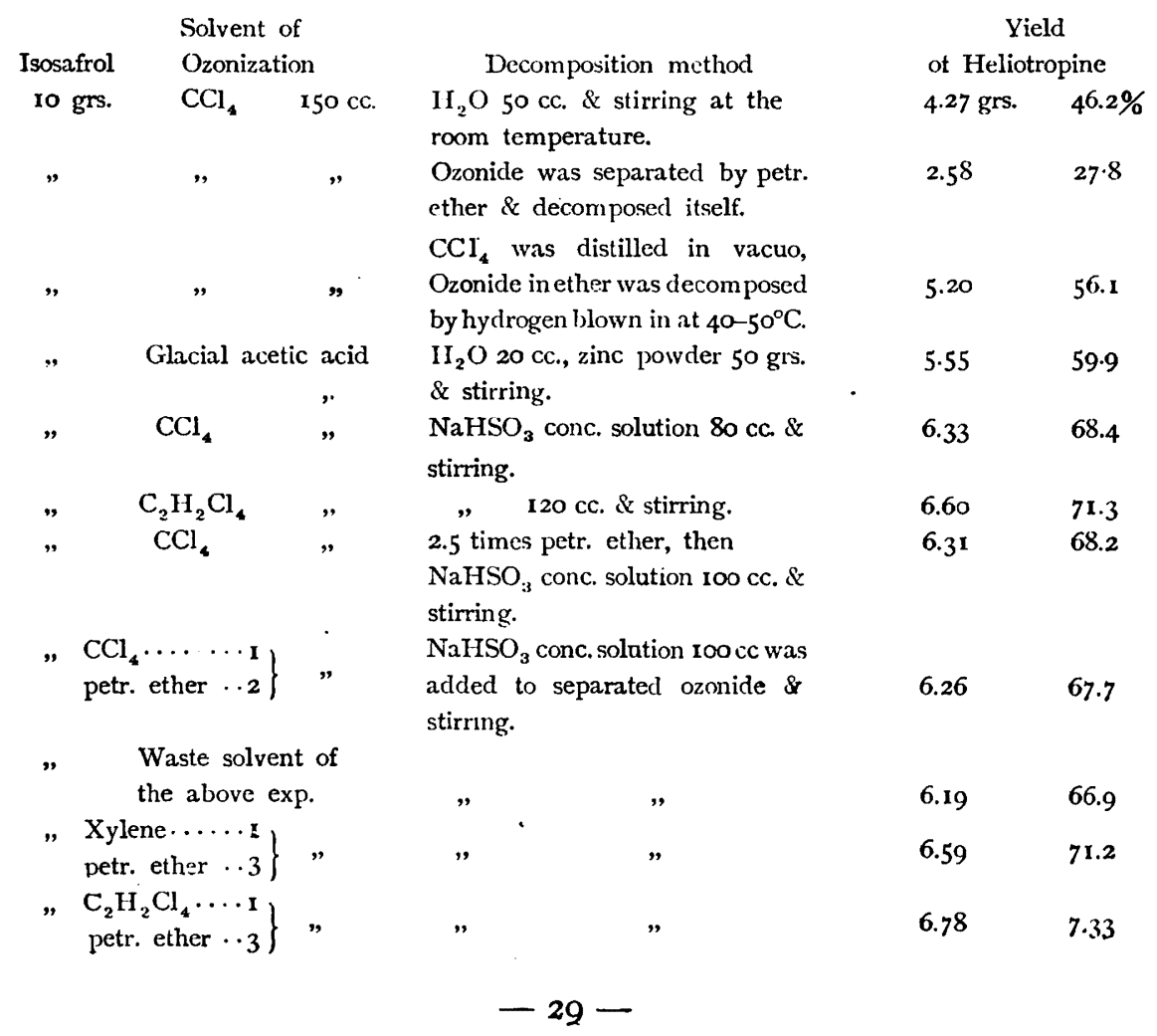




\begin{tabular}{|c|c|c|c|c|}
\hline 2) & $"$ & , & $\begin{array}{l}\text { By continuous ozonization \& } \\
\text { ozonide was decomposed by Na- } \\
\mathrm{HSO}_{3} \text { conc. solution \& stirring. }\end{array}$ & $\mathrm{I} 4 \cdot 3 \mathrm{I}$ \\
\hline 25 & " & $"$ & , & 18.47 \\
\hline 30 & " & , & , & 23.50 \\
\hline
\end{tabular}

(Applied Chemistry Department, Engineering Faculty,

Tokyo Imperial University, 'Tokyo, Japan.)

ON ALligator ANd CROCODile OILS.

Bỳ Shūmei Kobayashi.

[Received March 20, 1922]

(I) Alligator Oil.

The sample was obtained from an alligator (Alligator mississipiensis) from North America in the laboratory by boiling the fresh of the animal. It is a light yellow liquid of a peculiar fishy odour and defosited large amount of "stearine" at ordinary temperatures. In Tortelli-Jaffe's test a dirty yellowish green colouration was observed.

Sp. gr. $\left(15^{\circ} / 4^{\circ} \mathrm{C}\right)$

Acid, v.

0.9285

1.2

Iod. v. (Wijs)

Ref. index $\left(20^{\circ}\right)$

Saponif. v.

189.2

Unsaponif. matter

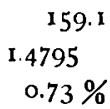

The unsaponifiable matter appears to consist mainly of cholesterol.

The mixed fatty acids had the following propertics:

$\begin{array}{lccr}\text { Melt. p. } & 27-28^{\circ} & \text { Ether-insoluble } \\ \text { Neutr. v. } & 196.8 & \text { bromide } & 46.2 \% \\ \text { Iod. v. } & 164.8 & \text { Br. content } & 70.25 \%\end{array}$

By the lithium-salt-acetone method (Tsujimoto) $25.1 \%$ of highly unsaturated acids was obtained. They had the neutr. value 173.3 , iodine value 367.6 and refractive index $\left(20^{\circ}\right) 1.4965$.

Examination of Fatty Acids.

The methyl-esters prepared from the mixed fatty acids freed from the unsaponifiable matter were brominated in ethereal solution and the insoluble bromides (a) were separated by filtration. The filtrate was treated with sodium thiosulphate in order to remove the excess of bromine; on evaporat- 
ing off the ether, the residue was treated with petroleum ether. The ins luble resinous product (b) formed was separated from the dark b:ownish-red coloured mother solution (c) by filtration.

(a) The precipitate was debrominated and the reformed methyl-esters were distilled under $5 \mathrm{~mm}$. pressure. Two fractions were obtaind which on saponification gave the following acids:

$\begin{array}{lcc} & \text { Acid (1) } & \text { Acid (2) } \\ \text { Sp. gr. }\left(15^{\circ} / 4^{\circ}\right) & 0.9300 & 0.9363 \\ \text { Neutr. v. } & 182.0 & 173.6 \\ \text { Iod. v. } & 346.4 & 359.3 \\ \text { Ref. inclex }\left(20^{\circ}\right) & \mathbf{1 . 4 9 1 2} & \mathbf{1 . 4 9 9 2}\end{array}$

The main constituent of the acid ( $\mathrm{I}$ ) was therefore recognized to be $\mathrm{C}_{20}$ $\mathrm{H}_{32} \mathrm{O}_{2}$ (arachidonic acid ?) and that of the acid (2) clupanodonic acid $\mathrm{C}_{22}$ $\mathrm{H}_{34} \mathrm{O}_{2}$.

(b) The precipitate from the petroleum ether solution contained $65.01 \%$ Br. It was debrominated and on saponification it gave the acid of the properties :

$$
\text { Neutr. value } 165.7 \quad \text { Iodine value } 308.0 \quad \text { Ref. inclex }\left(20^{\circ}\right) \mathrm{r} .4888
$$

On hydrogenation it gave an acid of m.p. $76-76.5^{\circ} \mathrm{C}$ and neutr. value I65. I.

The numerical data of this unsaturated acid correspond fairly well to those of a new acid of the composition $\mathrm{C}_{22} \mathrm{H}_{3 ;} \mathrm{O}_{2}\left(\mathrm{C}_{\mathrm{n}} \mathrm{H}_{2 \mathrm{n}-\mathrm{s}} \mathrm{O}_{2}\right.$ series $)$. That the acid is really a single chemical compound has not yet been ascertanied, but the author intends to make further investigation as soon as sufficient material has again been procured.

(c) The bromine addition compounds in the mother solution were distilled under $7 \mathrm{~mm}$. pressurc in order to separate the esters of saturated acids from those of unsaturated acids (Cp. Grün and Janko, Z. Deutsch. Öl-u.-Fett Ind., $192 \mathrm{I}, 553$.).

Between $160-180^{\circ} \mathrm{C}$ about $24 \%$ distilled over; the distillate was debrominated and saponified. The acid thus obtained had the iodine value II.8. On recrystallizing twice from alcohol it had the m.p. $62-62.3^{\circ} \mathrm{C}$ and neutr. value 217.2 ; so the substance has been recognized to be palmitic acid.

The distillation residue on similar treatment has been observed to consist 
mainly of oleic acid.

(2) Crocodile Oil.

The sample was obtained from the fresh of a crocodile (Crocodilus niloticus) from Africa. It is a solid fat at ordinary temperatures.

\begin{tabular}{lrrr} 
& \multicolumn{4}{c}{ Oil . } & \multicolumn{1}{c}{. } \\
Sp. gr. $\left(40^{\circ} / 4^{\circ}\right)$ & 0.8989 & Iod. . & . \\
Melt. p. & $30-33^{\circ}$ & Ref. index $\left(40^{\circ}\right)$ & $\mathrm{r} .4602$ \\
Acid v. & 2.1 & Unsaponif. m. & $0.97 \%$ \\
Saponif. v. & 195.4 & &
\end{tabular}

Fatty acids

Melt. p. $\quad 38-39^{\circ}$

Neutr. v. $\quad 203.7$

Iod. v. $\quad 63.6$

Ether-insol.

bromide $\quad \mathbf{1} .38 \%$

By the lead-salt ether method $52 \%$ of liquid acid was obtaind from the mixed acids.

$\begin{array}{lcr}\text { Appearance } & \begin{array}{c}\text { Liquid acids } \\ \text { light yellow liquid }\end{array} & \begin{array}{r}\text { solid acids } \\ \text { white solid }\end{array} \\ \text { Melt. p. } & & 52.5-53^{\circ} \\ \text { Neutr. v. } & 196.6 & 209.4 \\ \text { Iod. v. } & 92.6 & 6.1 \\ \text { Ret. index }\left(20^{\circ}\right) & - & 1.4612\end{array}$

Crocodile oil is probably a good raw material for soaps. 